\title{
A REVISED CHECKLIST OF PYRALOID MOTHS (LEPIDOPTERA: PYRALOIDEA) IN CROATIA
}

\section{Danijela Gumhalter}

Azuritweg 2, 70619 Stuttgart, Germany (e-mail: danijela.gumhalter@gmail.com)

Gumhalter, D.: A revised checklist of pyraloid moths (Lepidoptera: Pyraloidea) in Croatia. Nat. Croat., Vol. 28, No. 2., 271-288, Zagreb, 2019.

The first checklist of pyraloid moth species in Croatia, published in 2019, includes 362 species. A provisional checklist and bibliography of the Pyraloidea of the Balkan Peninsula was published in 2018, but because of unfortunate overlaps in timing, that work was not considered in the later publication. This present article provides new data on 16 additional species included in the earlier work. Taking these into account the number of Pyraloidea species occurring in Croatia raises to 377 and includes 207 Crambidae species plus 170 Pyralidae taxa. This represents about $45 \%$ of the European pyraloid moth fauna.

A revised checklist is presented now. Another 31 species, not included in the 2018 provisional checklist for the Balkan Peninsula, but which are listed in the 2019 Croatian checklist of Pyraloidea are also discussed. This is followed by a comparison with the pyraloid fauna of other countries from the region.

Keywords: Crambidae, Pyralidae, checklist, fauna, Croatia

Gumhalter, D.: Revidirani popis Pyraloidea (Lepidoptera: Pyraloidea) Hrvatske. Nat. Croat., Vol. 28, No. 2., 271-288, Zagreb, 2019.

Prvi popis vrsta Pyraloidea Hrvatske objavljen 2019. godine broji 362 vrste. Privremeni popis i bibliografija Pyraloidea Balkanskog poluotoka objavljeni su 2018. godine, no zbog nezgodnog vremenskog preklapanja nije uzeta u obzir pri izradi prvog popisa. Ovaj rad donosi nove podatke o 16 dodatnih vrsta iz spomenute publikacije. Uzevši istu u obzir, broj vrsta Pyraloidea u fauni Hrvatske raste na 377 vrsta. Ažurirani popis sada ukupno broji 207 vrsta por. Crambidae i 170 vrsta por. Pyralidae, što predstavlja oko $45 \%$ ukupne europske faune Pyraloidea.

Predstavljen je revidirani popis. Dodatna 31 vrsta koja nije navedena u privremenom popisu Balkanskog poluotoka, a koje su uvrštene u prvi hrvatski popis Pyraloidea, također su raspravljane. Usto, izvršena je usporedba sa susjednim državama regije.

Ključne riječi: Crambidae, Pyralidae, checklista, fauna, Hrvatska

\section{INTRODUCTION}

The Pyraloidea, comprising the families Crambidae and Pyralidae, are the third-largest superfamily of the Lepidoptera. The 15.576 described species (VAN Nieukerken et al., 2011) are distributed worldwide and belong to one of the most ecologically diverse superfamilies within the order Lepidoptera (REGIER et al., 2012). According to van Nieukerken et al. the family Crambidae currently includes 9.655 described species and the family Pyralidae 5.921 species worldwide. About 850 species of Pyraloidea can be found in Europe (KARsholt \& RAzowsKI, 1996).

Pyraloid larvae exhibit diverse behavioural characteristics. Some are concealed feeders that fold, roll, web, or tie leaves together to form a shelter. Others are borers 
of monocots and can be found in the stems, roots, shoots, buds, fruits or galls (Solis, 2007). Some groups of pyraloids have adapted to aquatic environments (Munroe, 1972) where they mostly feed on vascular plants or algae, but some have been observed as predators on other insects.

The existence of a checklist of pyraloid moths is important since the superfamily includes not only species of biological and ecological interest, but also species that are pests on agriculture and forestry. Some of their larvae are scavengers, feeding on stored products and causing economic damage. The superfamily Pyraloidea has the highest number of known species alien to Europe: 30 out of 97 non-native Lepidoptera species in Europe belong to this superfamily (LoPEz-VAAMONDE et al., 2010).

So a checklist should not only exist in order to conduct faunal surveys but also for biological or ecological research, for state agencies regulating pest species, spreading of alien species, etc. It could also improve the knowledge of the pyraloid moth fauna and increase the interest in this superfamily in general.

Until recently, there was no checklist of pyraloid moth species for Croatia. Information about the occurrence and distribution of the species was scattered over museum collections and different papers published over more than 200 years. As a result of extensive research through old and new literature, combined with examination of museum collections and unpublished results from private field surveys conducted from 2016 until 2018, the first checklist of pyraloid moth species in Croatia was presented by GumhaLter (2019). The intention of creating this list was primarily to summarize all available but scattered data on the species occurring in Croatia, and not to deal with possible species misidentifications from historical records.

Due to unpredicted circumstances, the provisional checklist and bibliography of the Pyraloidea of the Balkan Peninsula by Plant \& JAKšrć (2018) was not taken into account while creating the first checklist of pyraloid moth species in Croatia.

Plant \& JaKšić (2018) presented a helpful guideline for the countries of the Balkan Peninsula. In their work, which covered Albania, Bosnia-Herzegovina, Bulgaria, Croatia, Greece, North Macedonia, Montenegro, Romania, Serbia, Slovenia and the European part of Turkey (north of the Bosporus), literature references concerning the Pyraloidea in the region were listed and species extracted to the provisional checklist. Only on rare occasions, were comments made. Where a record was known with certainty to be incorrect, it was stated so, but otherwise, with few exceptions, only minimal policing of the validity of the data was undertaken and in general everything was included, without expressing an opinion. Plant \& JAKŠIć did not try to determine if the listed species remain extant within each country. They recorded altogether 344 species for the territory of Croatia, 194 Crambidae and 150 Pyralidae species.

All available new data on Pyraloidea species in Croatia are drawn together and a revised checklist of species is provided (Appendix 1). The distribution of additional 16 species in Europe and Croatia is discussed. A further 31 species 
which were listed by Gumhalter (2019), but which were not mentioned by Plant \& JAKŠić (2018) are also included.

\section{MATERIAL AND METHODS}

A comparison of the first Croatian checklist of Pyraloidea (Gumhalter, 2019) with the provisional checklist and bibliography of the Pyraloidea of the Balkan Peninsula was undertaken (Plant \& JAKšIć, 2018).

Data on the species which were not previously listed in the first Croatian checklist of Pyraloidea were extracted from the provisional checklist and bibliography of the Pyraloidea of the Balkan Peninsula. These additional species were listed in the checklist of Croatian pyraloid moths, which was hereby updated (Appendix 1).

Species, which were listed in the first Croatian checklist of Pyraloidea by Gumhalter, but have not been reported by PLANT \& JAKšIć, were also extracted from the listing and later on discussed.

\section{RESULTS AND DISCUSSION}

\section{Species listed for Croatia by Plant \& JaKšıć (2019) but which could not be included in the 2019 Croatian checklist}

Sixteen species were not previously listed in the first checklist of pyraloid moth species in Croatia (Gumhalter, 2019). It is possible that some of these findings or literature sources were simply overlooked throughout this extensive literature research.

By adding these species to the checklist, the number of Pyraloidea species occurring in Croatia rises to 377, a total of 207 Crambidae species and 170 Pyralidae species. This represents about 45\% of known pyraloid moth fauna in Europe.

It is interesting to compare this result with neighbouring countries. In Austria 314 species have been recorded, 195 from the family Crambidae and 119 from the family Pyralidae (Huemer, 2013). In Hungary 307 species of Pyraloidea have been recorded, 170 from the family Crambidae and 137 from the family Pyralidae (PAstorális, 2008). The Slovenian pyraloid moth fauna counts altogether 269 species, 168 from the family Crambidae and 101 from the family Pyralidae (LEsAR \& Govedič, 2010).

As published by Plant \& JAKšić (2018), the pyraloid moth fauna of Serbia counts 249 species, 93 from the family Crambidae and 156 from the family Pyralidae. In Bosnia-Herzegovina 236 species have been reported, 152 from the family Crambidae and 84 from the family Pyralidae. In Montenegro a total of 120 species have been recorded, 85 Crambidae and 35 Pyralidae species.

Croatia has a remarkably high number of Pyraloidea species in comparison with other countries in the region. Due to its geographic position through four biogeographical regions (Pannonian, Continental, Alpine, and Mediterranean) Croatia has a high floral and faunal biodiversity. The fauna of pyraloid moths in Croatia is likely much richer. 
Additions to this checklist are to be expected and all future updates and/or corrections are welcome.

For each of these additional sixteen species, the distribution in Europe is given. The distribution in Croatia is only given if it was available from the literature source cited by PLANT \& JAKšIĆ (2018):

Sciota fumella (Eversmann, 1844)

According to Fauna Europaea, this species is absent in the fauna of Croatia, but present in the fauna of Austria, Central European Russia, Czech Republic, Estonia, Finland, the French mainland, Hungary, the Italian mainland, Latvia, Lithuania, Poland, Romania, Slovakia, South European Russia, Switzerland and Ukraine.

The species was reported as a member of the Croatian pyraloid moth fauna by ŠAšićKLJAJO (2016).

Sciota rhenella (Zincken, 1818)

Fauna Europaea reports this species from Austria, Belgium, Bulgaria, Central European Russia, Czech Republic, the Danish mainland, Estonia, Finland, the French mainland, Germany, Hungary, the Italian mainland, Latvia, Lithuania, Poland, Romania, Slovakia, South European Russia, the Spanish mainland, Switzerland, and the Netherlands. It is not reported from Croatia.

Following Plant \& JAKŠIć (2018) the species was reported by ŠAšıć-KLJAJO (2016).

Phycita torrenti (Agenjo, 1962)

Fauna Europaea reports this species only from the Portuguese and the Spanish mainland. It is not mentioned by SLAMKA $(2006,2008,2013)$.

According to Pastorális \& Slamka (2015) and Plant \& Slamka (2016), it is also present in the fauna of Croatia. The latter state that it occurs in Croatian regions Kvarner and Dalmatia.

Acrobasis getuliella (Zerny, 1914)

Following Fauna Europaea, this species is present in the fauna of Croatia, as well as on Cyprus and Sicily.

ZERNY (1914) reported it from Pula in Istria.

Euzophera osseatella (Treitschke, 1832)

According to Fauna Europaea, this species is present in the fauna of Croatia. It is also present in Britain Is., Corsica, Cyprus, the French mainland, the Greek mainland, the Italian mainland, the Portuguese mainland, Sardinia, Sicily, and the Spanish mainland.

Euzophera osseatella is reported by NÁNDOR (1903) as being present in the Croatian fauna.

Dectocera pseudolimbella (Ragonot, 1887)

Fauna Europaea reports this species exclusively for the territory of Croatia.

RAGONOT (1887) and NÁNDOR (1903) are cited as a literature source for this species by PLANT \& JAKŠIĆ (2018).

Phycitodes bentickella (Pierce, 1937)

Although it is not listed in the Fauna Europaea database, this species is reported by RoESLER (1965) to be present in Croatia.

Ephestia unicolorella subsp. woodiella (Richards \& Thomson, 1932)

Following Fauna Europaea, the species Ephestia woodiella (Richards \& Thompson, 1932) is in this list treated as the subspecies Ephestia unicolorella subsp. woodiella (Richards \& 
Thomson, 1932). According to the database, it is present in the fauna of Croatia, as well as in Albania, Austria, Bosnia and Herzegovina, Britain Is., Bulgaria, Channel Is., Corsica, Czech Republic, East European Russia, European Turkey, the French mainland, Germany, the Greek mainland, Hungary, the Italian mainland, Kriti (Crete), Luxembourg, the Republic of North Macedonia, Malta, the Republic of Moldova, North Africa, Romania, Sardinia, Sicily, Slovakia, the Spanish mainland, Switzerland, the Netherlands, Ukraine, Serbia, and Montenegro.

PlANT \& JAKŠIĆ (2018) state that the species is reported as a member of the Croatian pyraloid moth fauna by MANN (1869), KLIMESCH (1942) and ŠAšić-KLJAJO (2016).

Catoptria pyramidellus (Treitschke, 1832)

Fauna Europaea does not report this species to be present in the fauna of Croatia. But it is present in Austria, Bulgaria, the French mainland, Germany, the Italian mainland, Slovenia, and Switzerland.

Slamka (2008) states that this montane species is distributed in the Alps, Apennines, Slovenia (Petrinjski karst), and Bulgaria.

ŠAšić-KLJAJO (2016) reports the species for Croatia.

Scoparia italica (Turati, 1919)

Fauna Europaea reports this species only from Austria, the Italian mainland, and Switzerland.

It is not mentioned by SLAMKA $(2006,2008,2013)$.

GoATER et al. (2015) and ŠAšić-KLJAJO (2016) report if for Croatia.

In the first checklist of Pyraloidea in Croatia (Gumhalter, 2019) Scoparia italica was considered as a synonym of Scoparia manifestella. However, according to GoATer et al. it is a separate species, which occurs in Switzerland, Austria, Italy, Slovenia, and Croatia. This suggestion is accepted and the species is in this checklist treated as a member of the Croatian fauna.

Eudonia laetella (Zeller, 1846)

According to Fauna Europaea this species is absent in the fauna of Croatia, but present in the fauna of Austria, Belarus, Belgium, Bosnia and Herzegovina, Czech Republic, Estonia, Finland, Germany, the Greek mainland, Hungary, the Italian mainland, Latvia, Lithuania, Luxembourg, the Republic of North Macedonia, the Norwegian mainland, Poland, Romania, Slovakia, Slovenia, Sweden, and Switzerland.

Eudonia laetella is not mentioned by SLAmKa $(2006,2008,2013)$.

Klima (1937) reports it from Croatia.

Eudonia phaeoleuca (Zeller, 1846)

Fauna Europaea reports it from Croatia, and also from Albania, Austria, Bosnia and Herzegovina, Bulgaria, European Turkey, the French mainland, Germany, the Greek mainland, the Italian mainland, the Republic of North Macedonia, Poland, Romania, Slovakia, the Spanish mainland, Switzerland, Serbia, and Montenegro.

There is no information on this species by SLAmKA $(2006,2008,2013)$.

It was mentioned as a member of the Croatian fauna in the work by AвAfi-Aigner from 1910.

Hyperlais argillacealis (Zeller, 1847)

Following fauna Europaea the species is present in the fauna of Croatia, the Greek mainland, Kriti (Crete), the Republic of North Macedonia, and Sicily.

Slamka $(2006,2008,2013)$ is not mentioning this species. 
The literature source that Plant \& JAKšIć (2018) give for this species is KHRAmov (2018), who is referring to the Fauna Europaea database.

Elophila rivulalis (Duponchel, 1834)

According to Fauna Europaea, Elophila rivulalis is present in the fauna of Croatia, as well as Austria, Belgium, Corsica, the French mainland, Germany, the Greek mainland, Hungary, the Italian mainland, Poland, Sardinia, Sicily, the Netherlands, and Ukraine.

SLAMKa $(2006,2008,2013)$ is not mentioning it.

Abafi-Aigner (1910) reported this species from Croatia.

Orenaia preisseckeri (Rebel 1903)

The species is not listed in the Fauna Europaea database, nor is it mentioned by SLAMKA (2006, 2008, 2013).

According to Fauna Europaea, Orenaia preisseckeri is a synonym of Orenaia alpestralis. But GOATER et al. (2015) consider them to be separate species, which is not taken into account by Fauna Europaea. Fauna Europaea does not report Orenaia alpestralis to be present in the fauna of Croatia. GoATer et al. (2015) report Orenaia preisseckeri for Croatia, which is now accepted in this article.

Epidauria strigosa (Staudinger, 1879)

Plant \& JAKšı́́ (2018) state that Polyocha strigosa (Staudinger, 1879) and Polyocha transversariella (Zeller, 1848) are probably one single species, but separated records of each taxon to allow future recognition. Fauna Europaea places both these taxa in genus Epidauria, rather than in Polyocha. This placement is followed in this paper.

Epidauria transversariella is reported by KLIMEsch (1942) from Dalmatia in Croatia. Epidauria strigosa is reported by Rebel (1891) also from Dalmatia in Croatia.

Following this practice, Epidauria strigosa has been now added to the checklist of pyraloid moths occurring in Croatia.

\section{Species included in the 2019 Croatian Checklist that are not listed by Plant \& JAKšıć (2018)}

Gumhalter (2019) included a further 31 pyraloid species that were not mentioned by Plant \& JAKŠIĆ (2018):

Parapoynx nivalis (Denis \& Schiffermüller, 1775)

The species has been reported by Plant \& JAKšıć only from Bosnia-Herzegovina, Serbia, Romania, and Bulgaria. It was not reported for the territory of Croatia.

But Gumhalter reports it from Croatia. Parapoynx nivalis was found by Rebel (1904) and in the Koča collection from the Croatian Natural History Museum in Zagreb.

According to Fauna Europaea, this species is absent in the fauna of Croatia.

Agriphila deliella (Hübner, 1813)

The species has been reported by them only from Slovenia, Bosnia-Herzegovina, Macedonia, Romania, and Bulgaria. Agriphila deliella was not reported for the territory of Croatia.

Gumhalter reports it from Croatia and cites Carnelutti (1994) and Habeler (2003). The species was also found in the Igalffy collection from the Croatian Natural History Museum in Zagreb.

According to Fauna Europaea, this species is absent in the fauna of Croatia. 
Calamotropha aureliellus (Fischer v. Röslerstamm, 1841)

They report it only from Slovenia, Serbia, Romania, Bulgaria, Macedonia, Albania, and Greece.

Gumhalter reports that the species has been found in the Koščec collection from the Entomological Department of the Varaždin City Museum (DuвоvečAк, 2010).

According to Fauna Europaea, this species is absent in the fauna of Croatia.

Catoptria fulgidella (Hübner, 1813)

PlAnT \& JAKšić (2018) report it from Romania, Bulgaria, Macedonia, and Greece.

Gumhalter reports it from Croatia only from the Igalffy collection.

According to Fauna Europaea, this species is absent in the fauna of Croatia.

Catoptria luctiferella (Hübner, 1813)

Catoptria luctiferella is reported just from Slovenia, Romania, and Bulgaria.

The only source Gumhalter gives is the Koča collection.

According to Fauna Europaea, this species is absent in the fauna of Croatia.

[Pediasia pedriolellus (Duponchel, 1836)

Plant \& JAKšić (2018) did not mention this species.

Reporting it from Croatia Gumhalter refers to SlamkA (2008). This is probably a misidentification since this is a species of high Alps in Slovenia, the Carpathians, and the Pyrenees only.

Also, according to Fauna Europaea, this species is absent in the fauna of Croatia.

For the time being it is still listed in this checklist.]

Anania luctualis (Hübner, 1793)

They report it from Slovenia, Bosnia-Herzegovina, Serbia, and Romania.

The only source Gumhalter gives is the Koča collection from the Croatian Natural History Museum in Zagreb.

According to Fauna Europaea, this species is present in the fauna of Croatia.

Ostrinia palustralis (Hübner, 1796)

This species is reported from Slovenia, Bosnia-Herzegovina, Romania, and Bulgaria.

Gumhalter reports it from Croatia and mentions MLAdinov (1978) as a literature source.

According to Fauna Europaea, this species is absent in the fauna of Croatia.

Gesneria centuriella (Denis \& Schiffermüller, 1775)

It is reported from Romania, Bulgaria, and Greece.

The only literature source Gumhalter gives is CARnELUtTI (1994).

According to Fauna Europaea, this species is absent in the fauna of Croatia.

Scoparia staudingeralis (Mabille, 1869)

According to Fauna Europaea, the species is reported from Balearic Is., Corsica, Cyprus, French and the Greek mainland, Kriti (Crete), the Portuguese mainland, Sardinia, the Spanish mainland, and Switzerland. It is absent in the fauna of Croatia.

Gumhalter reports this species from Croatia and refers to HABELER (2003).

Udea lutealis (Hübner, 1809)

It is reported from Slovenia, Bosnia-Herzegovina, Serbia, Romania, Bulgaria, Macedonia, Montenegro and Albania.

Gumhalter reports it from Croatia and cites Mann (1869), Rebel (1904) and Habeler (2003) as literature sources.

According to Fauna Europaea, this species is absent in the fauna of Croatia. 
[Aphomia unicolor (Staudinger, 1880)

This species is reported only from Romania, Bulgaria, and Greece.

Reporting it from Croatia Gumhalter refers to HABELER (2003).

According to Fauna Europaea, this species is absent in the fauna of Croatia.

Colin Plant (personal communication, June 2019) advises that the taxonomic status of Aphomia unicolor is uncertain and this taxon might only be a pale form of another species. Although the status is for the time being unclear, the species is still listed in the checklist until further investigations are undertaken.]

Peoria pectinella (Chrétien, 1911)

PLANT \& JAKŠIć (2018) did not mention this species.

Gumhalter states that "Seleucia pectinella has been recorded only once in the past. This finding was published in 1942 by Кцiмesch. In this checklist, it is treated as a member of the Croatian fauna as it is done in the Fauna Europaea database."

Leraut (2014) moved the species from the genus Seleucia to Peoria. This is subsequently accepted by Slamka (in prep.).

Acrobasis romanella (Millière, 1870)

The species is reported solely from Slovenia.

Gumhalter reports it from Croatia and cites HABeler (2003) as a source.

According to Fauna Europaea, this species is absent in the fauna of Croatia.

Dioryctria schuetzeella (Fuchs, 1899)

It is reported only from Slovenia and Romania.

Gumhalter reports it from Croatia and cites Carnelutti (1994) and Habeler (2003) as the only sources.

According to Fauna Europaea, this species is absent in the fauna of Croatia.

Ephestia kuehniella (Zeller, 1879)

Ephestia kuehniella is reported from Slovenia, Bosnia-Herzegovina, Serbia, Romania, Bulgaria, Albania, and Greece.

Gumhalter refers to CARNELutTI (1994) and reports it to be present in the fauna of Croatia. According to Fauna Europaea, this species is absent in the fauna of Croatia.

Eucarphia vinetella (Fabricius, 1787)

This species is reported exclusively from Romania.

Gumhalter refers to ManN (1857) and AbAfi-Aigner et al. (1896).

According to Fauna Europaea, this species is present in the fauna of Croatia.

Eurhodope incompta (Zeller, 1847)

It is reported from Slovenia, Macedonia, Greece, and the European part of Turkey.

Gumhalter gives HABELER (2003) as the only literature source for this species.

According to Fauna Europaea, this species is absent in the fauna of Croatia.

Euzophera fuliginosella (Heinemann, 1865)

They report it from Slovenia, Romania, Bulgaria, Macedonia, and Greece.

Gumhalter refers to HABELER (2003) as the only literature source.

According to Fauna Europaea, this species is present in the fauna of Croatia.

Faveria dionysia (Zeller, 1846)

The species is reported only from Greece.

Gumhalter reports it from Croatia and cites Rebel (1891) and Abafi-Aigner (1903) as references.

According to Fauna Europaea, this species is absent in the fauna of Croatia. 
Gymnancyla hornigii (Lederer, 1852)

Plant \& JaKšıć (2018) did not mention this species.

Gumhalter gives HABELER (2003) as a literature source for this species.

According to Fauna Europaea, this species is present in the fauna of Croatia.

Khorassania compositella (Treitschke, 1835)

They report it from Serbia, Romania, Bulgaria, Macedonia, Albania, and Greece.

Gumhalter gives following references for this species: Mann (1857, 1867), Rebel (1891), Abafi-Aigner et al. (1896), Neustetter (1956) and Habeler (2003).

According to Fauna Europaea, this species is present in the fauna of Croatia.

Merulempista cingillella (Zeller, 1846)

The species is reported from Slovenia, Romania, Macedonia, and Albania.

Gumhalter reports it from Croatia and cites Mann (1869), Rebel (1904), Neustetter (1956) and HABELER (2003) as sources.

According to Fauna Europaea, this species is present in the fauna of Croatia.

Metallosticha argyrogrammos (Zeller, 1847)

Metallosticha argyrogrammos is reported from Romania, Bulgaria, Macedonia, Montenegro, and Greece.

By reporting it from Croatia Gumhalter refers to Neustetter (1956).

According to Fauna Europaea, this species is absent in the fauna of Croatia.

Ortholepis betulae (Goeze, 1778)

They mention it for Slovenia, Bosnia-Herzegovina, and Romania.

Gumhalter reports it from Croatia and refers to HABELER (2003) as a literature source. The species has also been found in the Igalffy museum collection.

According to Fauna Europaea, this species is absent in the fauna of Croatia.

Pempelia brephiella (Staudinger, 1879)

The species is reported solely from Macedonia.

Gumhalter cites only CARNelutTI (1994) as a reference for this species.

According to Fauna Europaea, this species is absent in the fauna of Croatia.

[Phycita nephodeella (Ragonot, 1887)

Plant \& JAKšić (2018) state that "the basis of the report from Yugoslavia in Karsholt \& RAzowsKi (1996) cannot be traced".

Gumhalter mentions only the work from Rothschild (1914). For the time being it is still listed in this checklist, but further studies need to prove the occurrence of this species in Croatia.

According to Fauna Europaea, this species is absent in the fauna of Croatia.]

Phycitodes inquinatella (Ragonot, 1887)

This species is reported from Serbia, Romania, Bulgaria, Macedonia, Montenegro, Albania, Greece, and the European part of Turkey.

The only reference Gumhalter gives for this species is Koren (2018).

According to Fauna Europaea, this species is absent in the fauna of Croatia.

Phycitodes maritima (Tengström, 1848)

It is reported only from Romania, Bulgaria, and Greece.

Gumhalter reports it from Croatia by giving HABELER (2003) as a reference.

According to Fauna Europaea, this species is absent in the fauna of Croatia. 
Selagia subochrella (Herrich-Schäffer, 1849)

Plant \& JaKšić (2018) listed Selagia subochrella as a subspecies of Selagia argyrella - Selagia argyrella subochrella (Herrich-Schäffer, 1849). They report it from Bosnia-Herzegovina, Bulgaria, Macedonia, and Greece.

By reporting it from Croatia Gumhalter (2019) refers to Rebel (1916) and Carnelutti (1994).

According to Fauna Europaea, this species is absent in the fauna of Croatia.

For the time being Selagia subochrella and Selagia argyrella are treated as separate species.

Zophodia grossulariella (Hübner, 1809)

The species is reported only from Slovenia, Romania, and Greece.

The only source Gumhalter gives is the Igalffy collection from the Croatian Natural History Museum in Zagreb.

According to Fauna Europaea, this species is absent in the fauna of Croatia.

\section{Species rejected from the Croatian fauna}

One species, Phycita pedisignella (Ragonot, 1887), although reported by Plant \& JAKšIć (2018) from Croatia, was excluded from this checklist. Fauna Europaea reports this species only from the Greek mainland and the Republic of North Macedonia. Slamka $(2006,2008,2013)$ does not mention this species.

PLANT \& JAKŠIĆ (2018) cite the work by Plant \& SLAMKA (2016) as a literature source. But it is not mentioned there and therefore not treated as a member of the Croatian pyraloid moth fauna in this checklist.

Catoptria orientellus (Herrich-Schäffer, 1850)

According to Fauna Europaea, this species is absent in the fauna of Croatia and reported solely from Romania.

The only source Gumhalter cites is the Koča collection from the Croatian Natural History Museum in Zagreb, where 6 specimens have been found. Since the determination is questionable this secies is rejected from the Croatian pyraloid moth fauna.

\section{DISCUSSION}

The first checklist of pyraloid moth species occurring in Croatia included 362 species (Gumhalter, 2019). After comparing this checklist with the provisional checklist and bibliography of the Pyraloidea of the Balkan Peninsula (Plant \& JAKšIĆ, 2018), additional sixteen species have been listed in the checklist. The updated checklist now counts 377 species.

These additional sixteen species are: Sciota fumella, S. rhenella, Phycita torrenti, Acrobasis getuliella, Euzophera osseatella, Dectocera pseudolimbella, Phycitodes bentickella, Ephestia unicolorella subsp. woodiella, Catoptria pyramidellus, Scoparia italic, Eudonia laetella, E. phaeoleuca, Hyperlais argillacealis, Elophila rivulalis, Orenaia preisseckeri, and Epidauria strigosa.

A further 31 species that were not mentioned by Plant \& JAKšić (2018), but included in the 2019 Croatian checklist, were discussed.

Some of these 31 species have only been recorded in the past and need to be reconfirmed in future investigations: Parapoynx nivalis, Calamotropha aureliellus, 
Catoptria fulgidella, C. Iuctiferella, C. orientellus, Anania luctualis, Peoria pectinella, Eucarphia vinetella, Faveria dionysia, Phycita nephodeella and Zophodia grossulariella.

Other species were recently reported for the Croatian pyraloid moth fauna: Agriphila deliella, Scoparia staudingeralis, Acrobasis romanella, Dioryctria schuetzeella, Eurhodope incompta, Euzophera fuliginosella, Gymnancyla hornigii, Ortholepis betulae, Pempelia brephiella, Phycitodes inquinatella, and P. maritima. The majority of these species were recorded in an extensive survey conducted by HABELER in 2003.

Altogether three species from the list are marked as doubtfully present in the fauna of Croatia: Pediasia pedriolellus, a species of high Alps in Slovenia, the Carpathians and the Pyrenees only, Phycita nephodeella and Aphomia unicolor. The taxonomic status of the latter species is uncertain, as this taxon might only be a pale form of another species. Nontheless, all species are listed in the checklist until further investigations are undertaken.

One species, Phycita pedisignella, was excluded from this checklist. Although it was reported by PLANT \& JAKšıć (2018) from Croatia, it was not mentioned in the cited reference and therefore cannot be included in the checklist.

In this present article, Croatia is compared with neighbouring countries and shows a remarkably high number of Pyraloidea species occurring. With 377 species, Croatia has the richest pyraloid moth fauna among Austria (314), Hungary (307), Slovenia (369), Serbia (249), Bosnia-Herzegovina (236) and Montenegro (120). This represents about $45 \%$ of known pyraloid moth fauna in Europe.

It is important to mention that this data does not necessarily reflect the state of biodiversity. It is possible that the fauna of countries with lesser recorded species, like Bosnia-Herzegovina or Montenegro, is just insufficiently studied and requires further investigation.

In general terms, Croatia has a high floral and faunal biodiversity, which is due to its geographic position through four biogeographical regions (Pannonian, Continental, Alpine, and Mediterranean). Nonetheless, it remains questionable if this number reflects all species occurring in Croatia, or the real species number is higher or lower. There are still regions in Croatia, like the Mountainous or Continental parts, which are quite understudied. Also, some species reported only from historical records could maybe be misidentifications in the past. It is even possible that some species were present in the Croatian pyraloid moth fauna more than two hundred years ago, but are, caused by different reasons, now absent in the fauna of Croatia. It is to be expected, that these findings will either be reconfirmed throughout future investigations or that these species will be excluded from the list.

However, all future updates, corrections or additions of this list are welcome.

\section{AKNOWLEDGEMENTS}

I want to thank the reviewers for their careful reading of the manuscript and improving it with their valuable comments, corrections and suggestions. 


\section{REFERENCES}

Abafi-Aigner, L., Pavel, J. \& Uhryk, F. 1896: Fauna Regni Hungariae. Lepidoptera. Regia Societas Scientiarum Naturalium Hungarica, Budapest, 82 pp.

Abafi-Aigner, L., 1903: Adálek Microlepidopteráink ismeretéhez. Rovartani lapok 10 (7), $133-137$.

Abafi-Aigner, L., 1910: Adaléka Magyar Tengermellék, Horvátország és Dalmáczia lepkefaunájához. Rovartani lapok 17 (3-4), 55-57; (5-8), 71-105, [Pyralidae: 96-99], Budapest.

Carnelutti, J., 1994: Modernisiertes „Verzeichnis der bei Knin gesammelten Schmetterling (Lepidoptera)“ von Ivan Hafner. Natura Croatica 3 (2), 185-223.

Duвоvečaк, I., 2010: Faunističke i ekološke značajke porodice Pyralidae (Insecta, Lepidoptera) iz zbirke Franje Košćeca u Gradskom muzeju Varaždin. University of Zagreb, Faculty of Science, Department of Biology, Zagreb, 77 pp. (in Croatian)

FazeKas, I., 2009: Contribution to the Microlepidoptera fauna of Balkans, Nr. 1 (Lepidoptera). Natura Somogyiensis 15, 181-194.

Galvagni, E., 1902: Beiträge zur Kenntnis der Fauna einiger dalmatinischer Inseln. Verhandlungen der kaiserlich-königlichen zoologisch-botanischen Gesellschaft 52, 362-380.

Germar, E.F., 1817: Reise nach Dalmatien und in das Gebiet von Ragusa. F.A. Brockhaus, Leipzig, $323 \mathrm{pp}$.

Goater, B., Nuss, M. \& Speidel, W., 2005: Pyraloidea 1: Crambidae: Acentropinae, Evergestinae, Heliothelinae, Schoenobiinae, Scopariinae). In Huemer, P. \& O. Karsholt (Eds.) Microlepidoptera of Europe 4. Apollo Books, Stenstrup.

Gumhalter, D., 2019: First checklist of pyraloid moths (Lepidoptera: Pyraloidea) in Croatia. Zootaxa 4604 (1), 059-102. https://doi.org/10.11646/zootaxa.4604.1.3

Habeler, H. 2003: Die Schmetterlinge der Adria-Insel Krk. Eine ökofaunistische Studie. Buchreihe zur Entomologie Esperiana. Graz, 221 pp.

HAfNer, I., 1994: Verzeichnis der bei Knin gesammelten Schmetterlinge (Lepidoptera). Natura Croatica 3 (2), 119-184.

Huemer, P., 2013: Die Schmetterlinge Österreichs (Lepidoptera). Systematische und faunistische Checkliste. (Studiohefte 12). Tiroler Landesmuseen-Betriebsgesellschaft m.b.H. Innsbruck, 304 pp.

Karsholt, O. \& Razowski, J., 1996: The Lepidoptera of Europe (A Distributional Checklist). Apollo Books, Stenstrup, 280 pp.

Klima, A., 1937: Pyralididae: Subfam.: Scopariinae et Nymphulinae. In BryK, F. (Ed.). Lep. Cat.Part 84, Junk, Gravenhage.

Klimesch, J., 1942: Über Microlepidopteren-Ausbeuten aus der Gegend von Zaton bei Gravosa (Süddalmatien). Mitteilungen Münch. Ent. Gesellschaft 32 (2/3), 347-398, München.

Khramov, P., 2018: http://insecta.pro/taxonomy/9207

Koren, T. \& Zadravec, M., 2018: Three grass moths (Lepidoptera: Crambidae) new to the fauna of Croatia. Natura Croatica 27 (1), 239-242. DOI 10.20302/NC.2018.27.14

Leraut, P., 2008: Ebauche d'une liste des pyrales de France [Lepidoptera, Pyraloidea]. Revue française d'Entomologie (N.S.) 29 (4), 149-166.

Leraut, P., 2014: Moths of Europe 4: Pyralids 2. NAP Editions.

Lesar, T. \& Govedič, M., 2010: Check list of Slovenian Microlepidoptera. Natura Sloveniae 12 (1), 35-125.

Lopez-Vaamonde, C., Agassiz, D., Augustin, S., De Prins, J., De Prins, W., Gomboc, S., Ivinskis, P., Karsholt, O., Koutroumpas, A., Koutroumpa, F., Laštůvka, Z., Marabuto, E., Olivella, E., Przybylowicz, L., Roques, A., Ryrholm, N., Sefrova, H., Sima, P., Sims, I., Sinev, S., Skulev, B., Tomov, R., Zilli, A. \& Lees, D., 2010: Alien terrestrial arthropods of Europe, Chapter 11. Lepidoptera. BioRisk, 4, 603-668. https://doi.org/10.3897/biorisk.4.50

ManN, J., 1857: Verzeichnis der in Jahr 1853 in der Gegend von Fiume gesammelten Schmetterlinge. Wiener Entomol. Monatschrift 1(6), 161-189 [170-173 for Pyraloidea].

ManN, J., 1867: Schmetterlinge gesammelt im J. 1866 um Josefsthal in der Croat. Militärgrenze. Verhandlungen der Zoologisch-Botanischen Gesellschaft Wien, 63-76.

ManN, J., 1869: Lepidopteren gesammelt während dreier Reisen nach Dalmatien in den Jahren 1850, 1862 und 1869. Verhandlungen der Zoologisch-Botanischen Gesellschaft Wien 19, 371-388.

Mladinov, L., 1978: Ostrinia palustralis Hbn. nova vrsta u fauni leptira SR Hrvatske u Jugoslaviji (Microlepidoptera, Pyralidae). Acta entomologica Jugoslavica 14 (1-2), 115-116.

Munroe, E., 1972: Pyraloidea. Pyralidae (in part), Fasc. 13.1B. In: Dominick, R.B. et al. eds. The Moths of America North of Mexico. E. W. Classey, Ltd and the Wedge Entomological Research Foundation, London, pp. 137-250.

NÁNDor, U., 1903: A magyar lepke-fauna bővülése. Rovartani lapok 10 (4), 67-69; (5), 93-97.

Neustetter, H., 1956: Sammelreisen nach Dalmatien (Jugoslavien). Entomologisches Nachrichtenblatt 3 (3), 4-8. 
Nuss, M., Landry, B., Mally, R., Vegliante, F., Tränkner, A., Bauer, F., Hayden, J., Segerer, A., Schouten, R., Li, H., Trofimova, T., Solis, M.A., De Prins, J. \& Speidel, W., 2003-2017: Global Information System on Pyraloidea. Available from: http://www.pyraloidea.org (Accessed 20 April 2019)

Nuss, M., Speidel, W. \& Segerer, A., 2000-2013: Pyraloidea. In: Fauna Europaea Web Service. Version 2017.06. Available from: http://www.faunaeur.org. (Accessed 28 April 2019).

Pastorális, G., 2008: Checklist of the microlepidopteran fauna in Hungary. Natura Somogyiensis 10, 219-301.

Pastoralis, G. \& Slamka, F., 2015: Occurrence of Phycita torrenti Agenjo, 1962 in Hungary (Lepidoptera: Pyralidae, Phycitinae). Microlepidoptera.hu 8, 23-28.

Plant, C.W. \& Slamka, F., 2016: Re-examination and revision of Zeller's original concept of Phycita metzneri (Zeller, 1846) and description of Phycita cryptica sp. nov. (Lepidoptera, Pyraloidea, Pyralidae, Phycitinae). The Entomologist's Record and Journal of Variation 128 (1), 28-40.

Plant, C.W. \& JAKšıć, P., 2018: A provisional checklist and bibliography of the Pyraloidea of the Balkan Peninsula (Lepidoptera: Pyralidae \& Crambidae). Atalanta 49, 219-263.

Ragonot, E.-L., 1887: Diagnoses d'éspèces nouvelles de Phycitidae d'Europe et des pays limitrophes. Annales société entomologique de France series 6 7, 225-260, Paris.

Rebel, H., 1891: Beitrag zur Microlepidopteren-Fauna Dalmatiens. Verhandlungen der kaiserlichköniglichen zoologisch-botanischen Gesellschaft in Wien 41, 610-639.

Rebel, H., 1903: Studien über die Lepidopterenfauna der Balkanländer. I. Teil. Bulgarien und Ostrumelien. Annalen des Naturhistorischen Museums in Wien 18, 123-347.

Rebel, H., 1904: Studien über die Lepidopterenfauna der Balkanländer. II. Teil. Bosnien und Herzegowina. Annalen des Naturhistorischen Museums in Wien 19, 97-377.

Rebel, H., 1912: Lepidopteren aus dem Gebiete des Monte Maggiore in Istrien. I. Nachtrag. Jahresbericht des Wiener entomologischen Vereins 22, 227-240.

Rebel, H., 1914: Über die Lepidopterenfauna von Brioni grande. Jahresbericht des Wiener entomologischen Vereins 24, 181-201.

Rebel, H., 1916: Die Lepidopterenfauna Kretas. Annalen des Naturhistorischen Museums in Wien 30, 66-172.

Rebel, H. \& Zerny, H., 1934: Wissenschaftliche Ergebnisse der im Auftrage und mit Kosten der Akademie der Wissenschaften in Wien im Jahre 1918 entsendeten Expedition nach Nordalbanien. Die Lepidopterenfauna Albaniens (mit Berücksichtigung der Nachbargebiete). Denkschriften der Kaiserlichen Akademie der Wissenschaften 103, 37-161.

Regier, J.C., Mitter, C.E., Solis, M.A., Hayden, J.E., Landry, B., Nuss, M. \& Simonsen, T.J., 2012: A molecular phylogeny for the pyraloid moths (Lepidoptera: Pyraloidea) and its implications for higher-level classification. Systematic Entomology 37, 635-656. DOI: 10.1111/j.13653113.2012.00641.x

Roesler, U., 1965: Chorologische Untersuchungen über den Homoeosoma-Ephestia-Komplex (Lepidoptera: Phycitinae) im Paläarktischen Raum. Bonner Zoologische Beiträge 16, 318-349, Bonn.

Roтнschild, N.Ch., 1914: Adatok Magyarország lepkefaunájához. (Beiträge zur Lepidopterenfauna Ungarns). Rovartani lapok 21, 72-77.

SchAwERDA, K., 1921: Beiträge zur Lepidopterenfauna der kroatischen Küste und Neubeschreibungen. Deutsche Entomologische Zeitschrift Iris 35, 111-138.

Slamka, F., 2006: Pyraloidea of Europe (Lepidoptera). Vol. 1. F. Slamka, Bratislava, 138 pp.

Slamka, F., 2008: Pyraloidea of Europe (Lepidoptera). Vol. 2. Crambinae \& Schoenobiinae. F. Slamka, Bratislava, $224 \mathrm{pp}$.

Slamka F., 2013: Pyraloidea of Europe (Lepidoptera). Vol. 3. Pyraustinae \& Spilomelinae. F. Slamka, Bratislava, 357 pp.

Solis, M.A., 2007: Phylogenetic studies and modern classification of the Pyraloidea (Lepidoptera). Revista Colombiana de Entomología, 33, 1-8.

Staudinger, O., 1879: Lepidopteren-Fauna Kleinasien`s. Horae societas entomologicae rossicae 15, 159-435.

ŠAšić-KLJAJO, M., 2016: Završno izvješće za skupinu Lepidoptera: 188-226, maps, figs. In Hatić, D., Mrakovčić, M. \& Z. Mesić (Eds.), Projekt integracije u EU Natura 2000: Terensko istraživanje i laboratorijska analiza novoprikupljenih inventarizacijskih podataka za taksonomske skupine: Actinopterygii i Cephalaspidomorphi, Amphibia i Reptilia, Aves, Chiroptera, Decapoda, Lepidoptera, Odonata, Plecoptera, Trichoptera. [Lepidoptera on pages 188-226].

Van Nieukerken, E.J., Kaila, L. \& Kitching, I.J., 2011: Order Lepidoptera. Animal biodiversity: An outline of higher-level classification and survey of taxonomic richness. Zootaxa, 3148, 212-221.

ZERnY, H., 1914: Über palaarktische Pyraliden des k. k. naturhistorischen Hofmuseums in Wien inAnnalen des Kaiserlich-Königlichen Naturhistorischen Hofmuseums, Wien 28 (3-4), 295-348. 
APPENDIX 1. Updated checklist of Pyraloidea (Crambidae and Pyralidae) in Croatia. The list of species in each genus is organised alphabetically and the systematic presentation follows Fauna Europaea (Nuss et al., 2000-2013).

\section{Family Crambidae}

1. Cataclysta lemnata (Linnaeus, 1758)

2. Elophila nymphaeata (Linnaeus, 1758)

3. Elophila rivulalis (Duponchel, 1834)

4. Nymphula nitidulata (Hufnagel, 1767)

5. Parapoynx nivalis (Denis \& Schiffermüller, 1775)

6. Parapoynx stratiotata (Linnaeus, 1758)

7. Agriphila brioniellus (Zerny, 1914)

8. Agriphila dalmatinellus (Hampson, 1900)

9. Agriphila deliella (Hübner, 1813)

10. Agriphila geniculea (Haworth, 1811)

11. Agriphila inquinatella (Denis \& Schiffermüller, 1775)

12. Agriphila latistria (Haworth, 1811)

13. Agriphila paleatellus (Zeller, 1847)

14. Agriphila poliellus (Treitschke, 1832)

15. Agriphila selasella (Hübner, 1813)

16. Agriphila straminella (Denis \& Schiffermüller, 1775)

17. Agriphila tersellus (Lederer, 1855)

18. Agriphila tolli (Bleszyński, 1952)

19. Agriphila tristella (Denis \& Schiffermüller, 1775)

20. Ancylolomia palpella (Denis \& Schiffermüller, 1775)

21. Ancylolomia pectinatellus (Zeller, 1847)

22. Ancylolomia tentaculella (Hübner, 1796)

23. Angustalius malacellus (Duponchel, 1836)

24. Calamotropha aureliellus (Fischer v. Röslerstamm, 1841)

25. Calamotropha paludella (Hübner, 1824)

26. Catoptria acutangulellus (Herrich-Schäffer, 1847)

27. Catoptria falsella (Denis \& Schiffermüller, 1775)

28. Catoptria fulgidella (Hübner, 1813)

29. Catoptria languidellus (Zeller, 1863)

30. Catoptria luctiferella (Hübner, 1813)

31. Catoptria lythargyrella (Hübner, 1796)

32. Catoptria margaritella (Denis \& Schiffermüller, 1775)

33. Catoptria mytilella (Hübner, 1805)

34. Catoptria osthelderi (Lattin, 1950)

35. Catoptria pauperellus (Treitschke, 1832)

36. Catoptria petrificella (Hübner, 1796)

37. Catoptria pinella (Linnaeus, 1758)

38. Catoptria pyramidellus (Treitschke, 1832)

39. Catoptria verellus (Zincken, 1817)

40. Chilo phragmitella (Hübner, 1805)

41. Chrysocrambus cassentiniellus (HerrichSchäffer, 1848)

42. Chrysocrambus craterellus (Scopoli, 1763)

43. Chrysocrambus linetella (Fabricius, 1781)

44. Chrysoteuchia culmella (Linnaeus, 1758)

45. Crambus lathoniellus (Zincken, 1817)
46. Crambus pascuella (Linnaeus, 1758)

47. Crambus perlella (Scopoli, 1763)

48. Crambus pratella (Linnaeus, 1758)

49. Crambus silvella (Hübner, 1813)

50. Crambus uliginosellus (Zeller, 1850)

51. Euchromius bella (Hübner, 1796)

52. Euchromius cambridgei (Zeller, 1867)

53. Euchromius ocellea (Haworth, 1811)

54. Euchromius ramburiellus (Duponchel, 1836)

55. Euchromius superbellus (Zeller, 1849)

56. Mesocrambus candiellus (Herrich-Schäffer, 1848)

57. Metacrambus carectellus (Zeller, 1847)

58. Pediasia aridella (Thunberg, 1788)

59. Pediasia contaminella (Hübner, 1796)

60. Pediasia fascelinella (Hübner, 1813)

61. Pediasia jucundellus (Herrich-Schäffer, 1847)

62. Pediasia luteella (Denis \& Schiffermüller, 1775)

63. [Pediasia pedriolellus (Duponchel, 1836)]

64. Pediasia siculellus (Duponchel, 1836)

65. Platytes alpinella (Hübner, 1813)

66. Platytes cerussella (Denis \& Schiffermüller, 1775)

67. Talis quercella (Denis \& Schiffermüller, 1775)

68. Thisanotia chrysonuchella (Scopoli, 1763)

69. Xanthocrambus lucellus (Herrich-Schäffer, 1848)

70. Xanthocrambus saxonellus (Zincken, 1821)

71. Cybalomia lutosalis (Mann, 1862)

72. Hyperlais argillacealis (Zeller, 1847)

73. Hyperlais dulcinalis (Treitschke, 1835)

74. Hyperlais nemausalis (Duponchel, 1834)

75. Evergestis aenealis (Denis \& Schiffermüller, 1775)

76. Evergestis caesialis (Herrich-Schäffer, 1849)

77. Evergestis extimalis (Scopoli, 1763)

78. Evergestis forficalis (Linnaeus, 1758)

79. Evergestis frumentalis (Linnaeus, 1761)

80. Evergestis limbata (Linnaeus, 1767)

81. Evergestis pallidata (Hufnagel, 1767)

82. Evergestis politalis (Denis \& Schiffermüller, 1775)

83. Evergestis sophialis (Fabricius, 1787)

84. Orenaia preisseckeri (Rebel 1903)

85. Hellula undalis (Fabricius, 1775)

86. Hydriris ornatalis (Duponchel, 1832)

87. Eurrhypis guttulalis (Herrich-Schäffer, 1848)

88. Eurrhypis pollinalis (Denis \& Schiffermüller, 1775)

89. Aporodes floralis (Hübner, 1809)

90. Atralata albofascialis (Treitschke, 1829)

91. Cynaeda dentalis (Denis \& Schiffermüller, 1775)

92. Cynaeda gigantea (Wocke, 1871) 
93. Epascestria pustulalis (Hübner, 1823)

94. Tegostoma comparalis (Hübner, 1796)

95. Titanio normalis (Hübner, 1796)

96. Achyra nudalis (Hübner, 1796)

97. Anania coronata (Leraut, 2005)

98. Anania crocealis (Hübner, 1796)

99. Anania funebris (Ström, 1768)

100. Anania fuscalis (Denis \& Schiffermüller, 1775)

101. Anania hortulata (Linnaeus, 1758)

102. Anania lancealis (Denis \& Schiffermüller, 1775)

103. Anania luctualis (Hübner, 1793)

104. Anania perlucidalis (Hübner, 1809)

105. Anania stachydalis (Germar, 1821)

106. Anania terrealis (Tretischke, 1829)

107. Anania testacealis (Zeller, 1847)

108. Anania verbascalis (Denis \& Schiffermüller, 1775)

109. Ecpyrrhorrhoe diffusalis (Guenée, 1854)

100. Ecpyrrhorrhoe rubiginalis (Hübner, 1796)

111. Euclasta splendidalis (Herrich-Schäffer, 1848)

112. Loxostege aeruginalis (Hübner, 1796)

113. Loxostege clathralis (Hübner, 1813)

114. Loxostege comptalis (Freyer, 1848)

115. Loxostege deliblatica (Szent-Ivány \& UhrikMeszáros, 1942)

116. Loxostege fascialis (Hübner, 1796)

117. Loxostege mucosalis (Herrich-Schäffer, 1848)

118. Loxostege sticticalis (Linnaeus, 1761)

119. Loxostege turbidalis (Treitschke, 1829)

120. Loxostege virescalis (Guenée, 1854)

121. Nascia cilialis (Hübner, 1796)

122. Ostrinia nubilalis (Hübner, 1796)

123. Ostrinia palustralis (Hübner, 1796)

124. Ostrinia quadripunctalis (Denis \& Schiffermüller, 1775)

125. Paracorsia repandalis (Denis \& Schiffermüller, 1775)

126. Paratalanta hyalinalis (Hübner, 1796)

127. Paratalanta pandalis (Hübner, 1825)

128. Psammotis pulveralis (Hübner, 1796)

129. Pyrausta aerealis (Hübner, 1793)

130. Pyrausta aurata (Scopoli, 1763)

131. Pyrausta castalis (Treitschke, 1829)

132. Pyrausta cingulata (Linnaeus, 1758)

133. Pyrausta coracinalis (Leraut, 1982)

134. Pyrausta despicata (Scopoli, 1763)

135. Pyrausta falcatalis (Guenée, 1854)

136. Pyrausta nigrata (Scopoli, 1763)

137. Pyrausta obfuscata (Scopoli, 1763)

138. Pyrausta ostrinalis (Hübner, 1796)

139. Pyrausta purpuralis (Linnaeus, 1758)

140. Pyrausta sanguinalis (Linnaeus, 1767)

141. Pyrausta virginalis (Duponchel, 1832)

142. Sclerocona acutella (Eversmann, 1842)

143. Sitochroa palealis (Denis \& Schiffermüller, 1775)

144. Sitochroa verticalis (Linnaeus, 1758)
145. Uresiphita gilvata (Fabricius, 1794)

146. Donacaula forficella (Thunberg, 1794)

147. Donacaula mucronella (Denis \& Schiffermüller, 1775)

148. Schoenobius gigantella (Denis \& Schiffermüller, 1775)

149. Scirpophaga praelata (Scopoli, 1763)

150. Anarpia incertalis (Duponchel, 1832)

151. Cholius luteolaris (Scopoli, 1772)

152. Eudonia angustea (Curtis, 1827)

153. Eudonia delunella (Stainton, 1849)

154. Eudonia lacustrata (Panzer, 1804)

155. Eudonia laetella (Zeller, 1846)

156. Eudonia mercurella (Linnaeus, 1758)

157. Eudonia pallida (Curtis, 1827)

158. Eudonia phaeoleuca (Zeller, 1846)

159. Eudonia truncicolella (Stainton, 1849)

160. Eudonia vallesialis (Duponchel, 1832)

161. Gesneria centuriella (Denis \& Schiffermüller, 1775)

162. Heliothela wulfeniana (Scopoli, 1763)

163. Scoparia ambigualis (Treitschke, 1829)

164. Scoparia basistrigalis (Knaggs, 1866)

165. Scoparia ingratella (Zeller, 1846)

166. Scoparia italica (Turati, 1919)

167. Scoparia manifestella (Herrich-Schäffer, 1848)

168. Scoparia perplexella (Zeller, 1839)

169. Scoparia pyralella (Denis \& Schiffermüller, 1775)

170. Scoparia staudingeralis (Mabille, 1869)

171. Scoparia subfusca (Haworth, 1811]

172. Agrotera nemoralis (Scopoli, 1763)

173. Antigastra catalaunalis (Duponchel, 1833)

174. Cydalima perspectalis (Walker, 1859)

175. Diasemia reticularis (Linnaeus, 1761)

176. Diasemiopsis ramburialis (Duponchel, 1834)

177. Dolicharthria bruguieralis (Duponchel, 1833)

178. Dolicharthria punctalis (Denis \&

Schiffermüller, 1775)

179. Dolicharthria stigmosalis (Herrich-Schäffer, 1848)

180. Duponchelia fovealis (Zeller, 1847)

181. Herpetogramma licarsisalis (Walker, 1859)

182. Hodebertia testalis (Fabricius, 1794)

183. Mecyna asinalis (Hübner, 1819)

184. Mecyna balcanica (Slamka \& Plant, 2016)

185. Mecyna flavalis (Denis \& Schiffermüller, 1775)

186. Mecyna lutealis (Duponchel, 1833)

187. Mecyna trinalis (Denis \& Schiffermüller, 1775)

188. Metasia carnealis (Treitschke, 1829)

189. Metasia corsicalis (Duponchel, 1833)

190. Metasia ophialis (Treitschke, 1829)

191. Metasia rosealis (Ragonot, 1895)

192. Metasia suppandalis (Hübner, 1823)

193. Nomophila noctuella (Denis \& Schiffermüller, 1775)

194. Palpita vitrealis (Rossi, 1794) 
195. Pleuroptya crocealis (Duponchel, 1834)

196. Pleuroptya ruralis (Scopoli, 1763)

197. Spoladea recurvalis (Fabricius, 1775)

198. Udea accolalis (Zeller, 1867)

199. Udea ferrugalis (Hübner, 1796)

200. Udea fimbriatralis (Duponchel, 1834)

201. Udea fulvalis (Hübner, 1809)

202. Udea languidalis (Eversmann, 1842)

203. Udea lutealis (Hübner, 1809)

204. Udea nebulalis (Hübner, 1796)

205. Udea numeralis (Hübner, 1796)

206. Udea olivalis (Denis \& Schiffermüller, 1775)

207. Udea prunalis (Denis \& Schiffermüller, 1775)

\section{Family Pyralidae}

208. Achroia grisella (Fabricius, 1794)

209. Achroia grisella (Fabricius, 1794)

210. Galleria mellonella (Linnaeus, 1758)

211. Aphomia sociella (Linnaeus, 1758)

212. [Aphomia unicolor (Staudinger, 1880)]

213. Aphomia zelleri (Joannis, 1932)

214. Corcyra cephalonica (Stainton, 1866)

215. Lamoria anella (Denis \& Schiffermüller, 1775)

216. Anerastia lotella (Hübner, 1813)

217. Ematheudes punctella (Treitschke, 1833)

218. Epidauria strigosa (Staudinger, 1879)

219. Epidauria transversariella (Zeller, 1848)

220. Hypsotropa limbella (Zeller, 1848)

221. Hypsotropa vulneratella (Zeller, 1847)

222. Peoria pectinella (Chrétien, 1911)

223. Valdovecaria umbratella (Treitschke, 1832)

224. Cryptoblabes bistriga (Haworth, 1811)

225. Acrobasis advenella (Zincken, 1818)

226. Acrobasis bithynella (Zeller, 1848)

227. Acrobasis centunculella (Mann, 1859)

228. Acrobasis consociella (Hübner, 1813)

229. Acrobasis dulcella (Zeller, 1848)

230. Acrobasis fallouella (Ragonot, 1871)

231. Acrobasis glaucella (Staudinger, 1859)

232. Acrobasis getuliella (Zerny, 1914)

233. Acrobasis legatea (Haworth, 1811)

234. Acrobasis marmorea (Haworth, 1811)

235. Acrobasis obliqua (Zeller, 1847)

236. Acrobasis obtusella (Hübner, 1769)

237. Acrobasis porphyrella (Duponchel, 1836)

238. Acrobasis repandana (Fabricius, 1798)

239. Acrobasis romanella (Millière, 1870)

240. Acrobasis sodalella (Zeller, 1848)

241. Acrobasis suavella (Zincken, 1818)

242. Acrobasis tumidana (Denis \& Schiffermüller, 1775)

243. Alophia combustella (Herrich-Schäffer, 1855)

244. Amphithrix sublineatella (Staudinger, 1859)

245. Ancylosis cinnamomella (Duponchel, 1836)

246. Ancylosis oblitella (Zeller, 1848)

247. Ancylosis roscidella (Eversmann, 1844)
248. Apomyelois ceratoniae (Zeller, 1839)

249. Asalebria florella (Mann, 1862)

250. Assara conicolella (Constant, 1884)

251. Assara terebrella (Zincken, 1818)

252. Bradyrrhoa cantenerella (Duponchel, 1837)

253. Bradyrrhoa confiniella (Zeller, 1848)

254. Bradyrrhoa gilveolella (Treitschke, 1832)

255. Bradyrrhoa trapezella (Duponchel, 1836)

256. Cadra abstersella (Zeller, 1847)

257. Cadra calidella (Guenée, 1845)

258. Cadra cautella (Walker, 1863)

259. Cadra figulilella (Gregson, 1871)

260. Cadra furcatella (Herrich-Schäffer, 1849)

261. Catastia marginea (Denis \& Schiffermüller, 1775)

262. Delplanqueia dilutella (Denis \& Schiffermüller, 1775)

263. Dectocera pseudolimbella (Ragonot, 1887)

264. Denticera divisella (Duponochel, 1842)

265. Dioryctria abietella (Denis \& Schiffermüller, 1775)

266. Dioryctria mendacella (Staudinger, 1859)

267. Dioryctria pineae (Staudinger, 1859)

268. Dioryctria schuetzeella (Fuchs, 1899)

269. Dioryctria simplicella (Heinemann, 1863)

270. Dioryctria sylvestrella (Ratzeburg, 1840)

271. Eccopisa effractella (Zeller, 1848)

272. Elegia fallax (Staudinger, 1881)

273. Elegia similella (Zincken, 1818)

274. Ephestia elutella (Hübner, 1796)

275. Ephestia kuehniella (Zeller, 1879)

276. Ephestia unicolorella subsp. woodiella

(Richards \& Thomson, 1932)

277. Ephestia welseriella (Zeller, 1848)

278. Epischnia cretaciella (Mann, 1869)

279. Epischnia illotella (Zeller, 1839)

280. Epischnia leucoloma (Herrich-Schäffer, 1849)

281. Epischnia prodromella (Hübner, 1799)

282. Episcythrastis tabidella (Mann, 1864)

283. Episcythrastis tetricella (Denis \& Schiffermüller, 1775)

284. Etiella zinckenella (Treitschke, 1832)

285. Eucarphia vinetella (Fabricius, 1787)

286. Eurhodope cirrigerella (Zincken, 1818)

287. Eurhodope incompta (Zeller, 1847)

288. Eurhodope rosella (Scopoli, 1763)

289. Euzophera bigella (Zeller, 1848)

290. Euzophera cinerosella (Zeller, 1839)

291. Euzophera fuliginosella (Heinemann, 1865)

292. Euzophera osseatella (Treitschke, 1832)

293. Euzophera pinguis (Haworth, 1811)

294. Euzophera pulchella (Ragonot, 1887)

295. Euzopherodes charlottae (Rebel, 1914)

296. Euzopherodes lutisignella (Mann, 1869)

297. Euzopherodes vapidella (Mann, 1857)

298. Faveria dionysia (Zeller, 1846)

299. Glyptoteles leucacrinella (Zeller, 1848) 
300. Gymnancyla canella (Denis \& Schiffermüller, 1775)

301. Gymnancyla hornigii (Lederer, 1852)

302. Homoeosoma nebulella (Denis \& Schiffermüller, 1775)

303. Homoeosoma nimbella (Duponchel, 1837)

304. Homoeosoma sinuella (Fabricius, 1794)

305. Hypochalcia ahenella (Denis \& Schiffermüller, 1775)

306. Hypochalcia decorella (Hübner, 1810)

307. Hypochalcia dignella (Hübner, 1796)

308. Hypochalcia lignella (Hübner, 1796)

309. Insalebria serraticornella (Zeller, 1839)

310. Isauria dilucidella (Duponchel, 1836)

311. Khorassania compositella (Treitschke, 1835)

312. Matilella fusca (Haworth, 1811)

313. Merulempista cingillella (Zeller, 1846)

314. Metallosticha argyrogrammos (Zeller, 1847)

315. Metallostichodes bicolorella (Heinemann, 1864)

316. Metallostichodes nigrocyanella (Constant, 1865)

317. Moitrelia obductella (Zeller, 1839)

318. Myelois circumvoluta (Fourcroy, 1785)

319. Nephopterix angustella (Hübner, 1796)

320. Nyctegretis lineana (Scopoli, 1786)

321. Oncocera semirubella (Scopoli, 1763)

322. Ortholepis betulae (Goeze, 1778)

323. Oxybia transversella (Duponchel, 1836)

324. Pempelia albariella (Zeller, 1839)

325. Pempelia amoenella (Zeller, 1848)

326. Pempelia brephiella (Staudinger, 1879)

327. Pempelia palumbella (Denis \& Schiffermüller, 1775)

328. Pempeliella ornatella (Denis \& Schiffermüller, 1775)

329. Pempeliella sororiella (Zeller, 1839)

330. Phycita coronatella (Guenée, 1845)

331. Phycita cryptica (Plant \& Slamka, 2016)

332. Phycita meliella (Mann, 1864)

333. [Phycita nephodeella (Ragonot, 1887)]

334. Phycita poteriella (Zeller, 1846)

335. Phycita roborella (Denis \& Schiffermüller, 1775)

336. Phycita torrenti (Agenjo, 1962)

337. Phycitodes albatella (Ragonot, 1887)

338. Phycitodes bentickella (Pierce, 1937)

339. Phycitodes binaevella (Hübner, 1813)
340. Phycitodes inquinatella (Ragonot, 1887)

341. Phycitodes maritima (Tengström, 1848)

342. Plodia interpunctella (Hübner, 1813)

343. Psorosa dahliella (Treitschke, 1832)

344. Psorosa nucleolella (Möschler, 1866)

345. Psorosa tergestella (Ragonot, 1901)

346. Pterothrixidia rufella (Duponchel, 1836)

347. Rhodophaea formosa (Haworth, 1811)

348. Sciota adelphella (Fischer von Röslerstamm, 1836)

349. Sciota fumella (Eversmann, 1844)

350. Sciota insignella (Mann, 1862)

351. Sciota rhenella (Zincken, 1818)

352. Selagia argyrella (Denis \& Schiffermüller, 1775)

353. Selagia spadicella (Hübner, 1796)

354. Selagia subochrella (Herrich-Schäffer, 1849)

355. Trachonitis cristella (Denis \& Schiffermüller, 1775)

356. Vitula biviella (Zeller, 1848)

357. Zophodia grossulariella (Hübner, 1809)

358. Endotricha flammealis (Denis \&

Schiffermüller, 1775)

359. Hypotia corticalis (Denis \& Schiffermüller, 1775)

360. Hypotia massilialis (Duponchel, 1832)

361. Aglossa caprealis (Hübner, 1809)

362. Aglossa pinguinalis (Linnaeus, 1758)

363. Bostra obsoletalis (Mann, 1884)

364. Hypsopygia costalis (Fabricius, 1775)

365. Hypsopygia fulvocilialis (Duponchel, 1834)

366. Hypsopygia glaucinalis (Linnaeus, 1758)

367. Hypsopygia incarnatalis (Zeller, 1847)

368. Hypsopygia rubidalis (Denis \& Schiffermüller, 1775)

369. Loryma egregialis (Herrich-Schäffer, 1838)

370. Pyralis farinalis (Linnaeus, 1758)

371. Pyralis regalis (Denis \& Schiffermüller, 1775)

372. Stemmatophora brunnealis (Treitschke, 1829)

373. Stemmatophora combustalis (Fischer von Röslerstamm, 1842)

374. Stemmatophora honestalis (Treitschke, 1829)

375. Synaphe antennalis (Fabricius, 1794)

376. Synaphe bombycalis (Denis \& Schiffermüller, 1775)

377. Synaphe moldavica (Esper, 1794)

370. Synaphe punctalis (Fabricius, 1775) 
